\title{
Dynamic correlation between induction of the expression of heme oxygenase- 1 and hepatitis $B$ viral replication
}

\author{
YU-MING SHEN ${ }^{1}$, HONG-LI ZHANG ${ }^{1}$, YI-HANG WU ${ }^{1,2}$, XIAO-PING YU $^{1}$, HUA-JUN HU $^{1}$ and LING-HAO DAI ${ }^{1}$ \\ ${ }^{1}$ Department of Pharmacy, Zhejiang Provincial Key Laboratory of Biometrology and Inspection and Quarantine, \\ College of Life Sciences, China Jiliang University, Hangzhou, Zhejiang 310018, P.R. China; \\ ${ }^{2}$ Department of Medicinal Chemistry and Molecular Pharmacology, College of Pharmacy, \\ Purdue University, West Lafayette, IN 47907, USA
}

Received May 2, 2014; Accepted January 9, 2015

DOI: $10.3892 / \mathrm{mmr} .2015 .3278$

\begin{abstract}
Heme oxygenase-1 (HO-1) possesses significant potential as a drug target for hepatitis $\mathrm{B}$, which may be transferable to patient therapy. The aim of the present study was to clarify the dynamic correlation between the hepatitis $\mathrm{B}$ virus (HBV) and HO-1. The levels of HBV replication and expression of HO-1 were investigated in HepG2.2.15 hepatoma cells following exposure to 5-50 $\mu \mathrm{M}$ hemin for 1-6 days. The mRNA expression levels of HO-1 were then detected using reverse transcription-quantitative polymerase chain reaction (RT-qPCR). HBV replication levels were determined by enzyme-immunoassay and a PCR-fluorescence quantitation assay. The results of the present study demonstrated that the mRNA expression levels of HO-1 increased in a dose-dependent manner in the HepG2.2.15 cells, following exposure to 5-50 $\mu \mathrm{M}$ hemin. The mRNA expression levels of HO-1 reached a peak following exposure of the cells to hemin for three days, subsequently the expression of HO-1 decreased. Following exposure to hemin at an optimal concentration of $50 \mu \mathrm{M}$ for 1-6 days, the levels of the hepatitis B surface antigen ( $\mathrm{HBsAg}$ ) and hepatitis $\mathrm{B}$ e antigen $(\mathrm{HBeAg})$ in the cells were significantly reduced. This marked reduction in the expression of HBsAg and $\mathrm{HBeAg}$ reached its peak on the first day, following which the inhibition weakened as the duration of exposure increased. In addition, the inhibition of HBV DNA replication increased with the a longer duration of exposure. Furthermore, HBV DNA levels were significantly decreased following exposure to hemin for 3-6 days. In conclusion, the present study demonstrated that induced expression of $\mathrm{HO}-1$ interfered with HBV replication in a dose and time-dependent
\end{abstract}

Correspondence to: Dr Yi-Hang Wu, Department of Pharmacy, Zhejiang Provincial Key Laboratory of Biometrology and Inspection and Quarantine, College of Life Sciences, China Jiliang University, 258 Xueyuan Street, Xiasha Higher Education Zone, Hangzhou, Zhejiang 310018, P.R. China

E-mail: yihangwu@126.com

Key words: heme oxygenase-1, hemin, hepatitis B virus, dynamic correlation manner, implying that a reduction of the HBV viral load may contribute to upregulation in the expression of HO-1.

\section{Introduction}

Hepatitis B is the most common severe hepatic infection worldwide. The causative agent of hepatitis B is the hepatitis B virus (HBV), which attacks the liver. There is currently no complete cure for chronic hepatitis B. The drugs currently used to treat hepatitis B slow the progression of liver disease, by suppressing the virus. If less HBV is produced, less liver damage occurs (1). However, the current anti-HBV drugs, including interferon- $\alpha$ and nucleoside analogues, have certain disadvantages, including the rebound phenomenon of $\mathrm{HBV}$ replication following withdrawal of treatment and unpleasant side effects (2). Furthermore, a significant number of patients develop drug resistance following long-term use of these therapeutic agents (3). Therefore, further investigation is required, in order to develop novel anti-HBV agents.

Heme oxygenases $(\mathrm{HO})$ are rate-limiting enzymes in heme catabolism. They catalyze the oxidative degradation of heme to carbon monoxide, free iron and biliverdin, which is subsequently converted to bilirubin by the bilirubin reductase enzyme $(4,5)$. Among the three known heme oxygenase isoforms, HO-1, HO-2 and HO-3; HO-1 is the only inducible form present in almost every type of cell (6). The induction, overexpression or inhibition of HO-1 degradation has been observed to interfere with acute and chronic liver inflammation and fibrotic progression, apoptotic liver damage, replication of hepatitis $\mathrm{B}$ and $\mathrm{C}$ viruses or protection of liver grafts from ischemia/reperfusion injury, caused by either transplantation or hemorrhage/resuscitation (7). Therefore, HO-1 possesses significant curative potential, particularly for patients with hepatitis B and C, predominantly due to its anti-inflammatory, anti-apoptotic, antifibrotic and antiviral properties (7).

The induction of HO-1 directly represses HBV replication in hepatocytes at the post-transcriptional level by reducing the stability of the HBV core protein, therefore inhibiting the refill of nuclear HBV covalently closed circular DNA (HBV cccDNA) (8). Small interfering (si)RNA, directed against HO-1 demonstrated that this effect is dependent on the expression of HO-1 (7). Therefore, the induction of HO-1 
may be a novel therapeutic option for hepatitis B-associated inflammation. Although HO-1 has been observed to exhibit pronounced antiviral properties, the dynamic association between HBV replication and the expression of HO-1 remains to be elucidated. The present study aimed to investigate the overexpression of HO-1 induced by hemin, and to discuss the dynamic association between HBV replication and the induction of HO-1 in HBV-transfected HepG2.2.15 cells.

\section{Materials and methods}

Reagents. Fetal bovine serum, hemin and Dulbecco's modified Eagle's medium (DMEM) were purchased from Gibco Life Technologies (Grand Island, NY, USA). 3-(4,5-dimethylthiazol-2-yl)-2,5-diphenyltetrazolium bromide (MTT) was purchased from Sigma-Aldrich (St. Louis, MO, USA). A HBV DNA polymerase chain reaction (PCR)-fluorescence quantitation kit and enzyme-immunoassay (EIA) kits for the detection of hepatitis B surface antigen ( $\mathrm{HBsAg}$ ) and hepatitis B e antigen (HBeAg) were obtained from Shanghai Kehua Bio-engineering Co., Ltd (Shanghai, China). G418 was purchased from Invitrogen Life Technologies (Carlsbad, CA, USA). SYBR ${ }^{\circledR}$ Premix Ex $\mathrm{Taq}^{\mathrm{TM}}$, RNAiso Plus, a Prime Script Reverse Transcription (RT) Reagent kit and DNA ladder marker were obtained from Takara Biotechnology Co., Ltd. (Dalian, China). All other reagents were of the highest commercial grade available.

Cytotoxicity of hemin on HepG2.2.15 cells. HBV-transfected HepG2.2.15 hepatoma cells $\left(5.0 \times 10^{4}\right.$ cells $\left./ \mathrm{ml}\right)$ were provided by the State Key Laboratory for Diagnosis and Treatment of Infectious Diseases at Zhejiang University (Zhejiang, China) (9) and maintained in DMEM supplemented with $2 \mathrm{mM}$ glutamine, $10 \%(\mathrm{v} / \mathrm{v})$ heat-inactivated fetal bovine serum and $380 \mu \mathrm{g} / \mathrm{ml} \mathrm{G} 418$ at $37^{\circ} \mathrm{C}$ in a $95 \%$ humidified atmosphere containing $5 \% \mathrm{CO}_{2}$. Hemin-induced cytotoxicity was analyzed using an MTT assay. Briefly, the cells were seeded in a 96 -well plate $\left(5.0 \times 10^{4}\right.$ cells $/ \mathrm{ml} ; 200 \mu \mathrm{l} /$ well $)$. Different concentrations of hemin $(5,10,20,50,75$ and $100 \mu \mathrm{M})$ were applied to the culture wells in triplicate. The cells were then incubated for six days and $10 \mu \mathrm{l}$ MTT $(5 \mathrm{mg} / \mathrm{ml})$ was then added to the cells in each well. Following $4 \mathrm{~h}$ culture at $37^{\circ} \mathrm{C}$ (95\% humidity; $5 \% \mathrm{CO}_{2}$ ), the medium was removed, and the blue formazan crystals, which had formed, were dissolved in $150 \mu \mathrm{l}$ dimethyl sulfoxide (Sigma-Aldrich). The absorbance of the formazan generated from MTT was measured at a wavelength of $570 \mathrm{~nm}$ using a Multi-Well microplate reader (Multiskan MK3; Thermo Fisher Scientific Inc., Waltham, MA, USA). The cytotoxicity of hemin was defined according to the quantity of formazan produced relative to that produced by the untreated cells, and was expressed as cell viability.

Hemin-induced expression of HO-1 in HepG2.2.15 cells. HepG2.2.15 cells were seeded in six-well plates $\left(5.0 \times 10^{4}\right.$ cells $\left./ \mathrm{ml}\right)$ and were treated with various concentrations of hemin $(5,10,20$ and $50 \mu \mathrm{M}$ ) for 1-6 days, respectively. The mRNA expression of HO-1 was detected using quantitative (q)PCR. Total RNA was extracted from the HepG2.2.15 cells using RNAiso Plus reagent, followed by recombinant DNase I (RNase-free; Takara Biotechnology Co., Ltd) digestion. The RNA was reverse transcribed into cDNA using the Prime Script RT reagent kit, according to the manufacturer's instructions. The products of reverse transcription served as a template for qPCR. qPCR was performed with SYBR Premix Ex Taq (Tli RNaseH Plus) using a Bio-Rad iQ5 Real Time PCR system (Bio-Rad Laboratories, Inc., Hercules, CA, USA). $\beta$-actin was used as an internal control. The primers for HO- 1 and $\beta$-actin were specifically designed according to the mRNA sequences of human HO-1 and $\beta$-actin, obtained from Genbank (http://blast.st-va.ncbi.nlm. nih.gov/Blast.cgi?CMD=Web\&PAGE_TYPE=BlastHome).

The following primer sequences were used: HO-1, forward 5'-TTGCCAGTGCCACCAAGTTC-3', reverse 5'-TCAGCAGCTCCTGCAACTCC-3'; and $\beta$-actin, forward 5'-TGGCACCCAGCACAATGAA-3', and reverse 5'-CTAAGTCATAGTCCGCCTAGAAGCA-3'. The thermal program comprised of an initial denaturation at $95^{\circ} \mathrm{C}$ for $30 \mathrm{sec}$, followed by 40 amplification cycles, each containing two steps: $95^{\circ} \mathrm{C}$ for $5 \mathrm{sec}$ and $60^{\circ} \mathrm{C}$ for $1 \mathrm{~min}$. The target gene fragments were analyzed using gel electrophoresis (2\% agarose; Biowest SAS, Nuaillé, France), to verify the specificity of the primers. To check the purity of the products, a melting curve analysis was performed after each run. Relative quantification was conducted using the cycle threshold $(\mathrm{Ct})$ values, which were determined for triplicate reactions for the assessed and reference samples for each target gene, and for the internal control gene ( $\beta$-actin). The relative expression levels were determined using the $2^{-\Delta \Delta \mathrm{Ct}}$ quantification method, where ${ }^{\Delta \Delta \mathrm{Ct}}={ }^{\Delta \mathrm{Ct}}$ (target sample) $-{ }^{\Delta \mathrm{Ct}}$ (reference sample) (10).

$H B V$ replication in HepG2.2.15 cells treated with hemin. The medium, in which the HepG2.2.15 cells treated with hemin for 1-6 days, was used to measure the HBsAg, HBeAg and HBV DNA levels. The levels of HBsAg and HBeAg in the culture supernatants were determined using EIA kits, according to the manufacturer's instructions. The absorbance was measured at $450 \mathrm{~nm}$ using a multi-well plate reader. The HBV viral load in the culture supernatants was detected using a HBV DNA PCR-fluorescence quantitation kit. Briefly, viral DNA from HBV virions present in the cell culture supernatants was extracted and amplified using the Bio-Rad iQ5 Real Time PCR system. The primer sequences were as follows: Forward 5'-CCGTCTGTGCCTTCTCATCTG-3', and reverse 5'-AGTCCAAGAGTACTCTTATAGAAGACCTT-3'. The Taqman probe sequence was: FAM-CCGTGTGCACTTCG CTTCACCTCTGC. The thermal program comprised of an initial denaturation at $94^{\circ} \mathrm{C}$ for $2 \mathrm{~min}$, followed by 40 amplification cycles each containing two steps: $95^{\circ} \mathrm{C}$ for $5 \mathrm{sec}$ and $60^{\circ} \mathrm{C}$ for $30 \mathrm{sec}$. A plasmid containing the HBV genome was used to prepare the standard curve.

Dynamic correlation between $\mathrm{HO}-1$ induction and $\mathrm{HBV}$ replication. Preliminary investigations indicated that $50 \mu \mathrm{M}$ hemin is the maximum non-toxic concentration on HepG2.2.15 cells, and is the optimal concentration for the induction of HO-1 (Table I). To further determine the dynamic correlation between the induction of HO-1 and the replication of $\mathrm{HBV}$, overexpression of HO-1 was induced using $50 \mu \mathrm{M}$ hemin, and its effects on HBV replication were investigated in the HepG2.2.15 cells. HepG2.2.15 cells were treated with $50 \mu \mathrm{M}$ hemin for 1-6 days. The expression levels of HO-1 in the cells treated with hemin for different durations were determined 
Table I. Cytotoxicity of hemin in HepG2.2.15 cells.

\begin{tabular}{lcrr}
\hline Group & Hemin concentration $(\mu \mathrm{M})$ & Absorbance at $570 \mathrm{~nm}$ & Cell survival $(\%)$ \\
\hline Vehicle & - & $1.586 \pm 0.058$ & 100.000 \\
Hemin & 5 & $1.675 \pm 0.042$ & 105.612 \\
& 10 & $1.535 \pm 0.112$ & 96.784 \\
& 20 & $1.435 \pm 0.103$ & 90.479 \\
& 50 & $1.446 \pm 0.101$ & 91.173 \\
& 75 & $1.377 \pm 0.147^{\mathrm{a}}$ & 86.822 \\
& 100 & $1.259 \pm 0.055^{\mathrm{b}}$ & 79.382 \\
\hline
\end{tabular}

Cells were treated with hemin at various concentrations (5-100 $\mu \mathrm{M})$ for six days. The cytotoxicity of hemin in the cells was determined using an MTT assay. All determinations were replicated four times and values are expressed as the mean \pm standard deviation. ${ }^{a} \mathrm{P}<0.05$ and ${ }^{\mathrm{b}} \mathrm{P}<0.01$, compared with the vehicle control. $0.1 \%$ ammonia water was used as the vehicle control.

using qPCR, as described above. The HBsAg and HBeAg levels in the culture supernatants were determined using EIA kits. The HBV viral load the in culture supernatants were detected using a HBV DNA PCR-fluorescence quantitation kit.

Statistical analysis. The experimental data are expressed as the mean \pm standard deviation. The results were subjected to one-way analysis of variance and Student's t-test in order to determine significance. Statistical analyses were performed using SPSS 10.0 software (SPSS, Inc., Chicago, IL, USA). P<0.05 was considered to indicate a statistically significant difference.

\section{Results}

Cytotoxicity analysis of hemin. The cytotoxicity of hemin on HepG2.2.15 cells was determined using an MTT assay. Hemin was non-toxic to the cells when used at a concentration between 5 and $50 \mu \mathrm{M}$ for six days (Table I). Following exposure to $50 \mu \mathrm{M}$ hemin for six days, cell viability was $91.17 \%$. The maximum non-toxic concentration of hemin on HepG2.2.15 cells was $50 \mu \mathrm{M}$, whereas treatment with hemin at concentrations between 75 and $100 \mu \mathrm{M}$ produced a significant decrease in cell viability. Cell viability was 86.82 and $79.38 \%$ following exposure to 75 and $100 \mu \mathrm{M}$ hemin for six days, respectively.

Hemin induces the expression of $\mathrm{HO}-1$. The mRNA expression levels of hemin-induced HO-1 were determined in the HepG2.2.15 cells by qPCR (Fig. 1). Treatment with hemin at 5-50 $\mu \mathrm{M}$ significantly increased the expression levels of $\mathrm{HO}-1$ in a dose-dependent manner. Exposure of the cells to hemin for different durations resulted in an elevation in the mRNA expression levels of HO-1 (Fig. 2). Furthermore, the mRNA expression of HO-1 peaked following exposure to 5-50 $\mu \mathrm{M}$ hemin for three days, whereas the mRNA expression levels began to decrease as the duration of exposure to hemin increased further.

Effects of hemin on $H B V$ replication. The levels of HBsAg and $\mathrm{HBeAg}$ were detected in the HepG2.2.15 cell culture supernatants following incubation with hemin (5-50 $\mu \mathrm{M})$ for 1-6 days. The expression of HBsAg was significantly inhibited in the HepG2.2.15 cells following exposure to 5-50 $\mu \mathrm{M}$ hemin (Fig. 3). In addition, the expression of $\mathrm{HBeAg}$ was markedly reduced

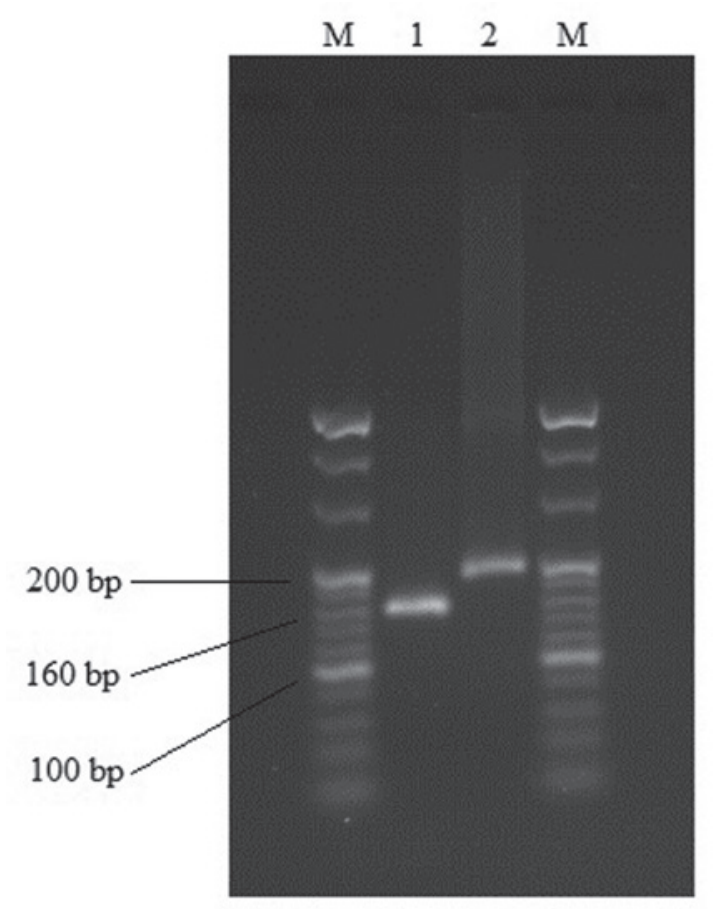

Figure 1. Polymerase chain reaction amplification products of HO-1 and $\beta$-actin. Lane M, DNA marker (molecular weight standard); lane 1, HO-1; lane $2, \beta$-actin. $\beta$-actin was used as an internal control. HO-1, heme oxygenase-1; Bp, base pairs.

in the cells following exposure to 5-50 $\mu \mathrm{M}$ hemin (Fig. 4). Furthermore, as the duration of exposure to hemin, increased, the inhibitory trend was less marked. The DNA expression levels of HBV were determined in the culture supernatants following treatment of the cells with hemin $(5-50 \mu \mathrm{M})$ for 1-6 days. HBV DNA replication was markedly inhibited following exposure to hemin, and this trend of inhibition became more marked as the duration of exposure increased (Fig. 5).

Correlation between the expression of $\mathrm{HO}-1$ and $\mathrm{HBV}$ replication. To further analyze the dynamic association between the induction of HO-1 and HBV replication, the expression of HO-1 was induced in HepG2.2.15 cells with hemin, at an optimal concentration of $50 \mu \mathrm{M}$, for 1-6 days (Table II). The 


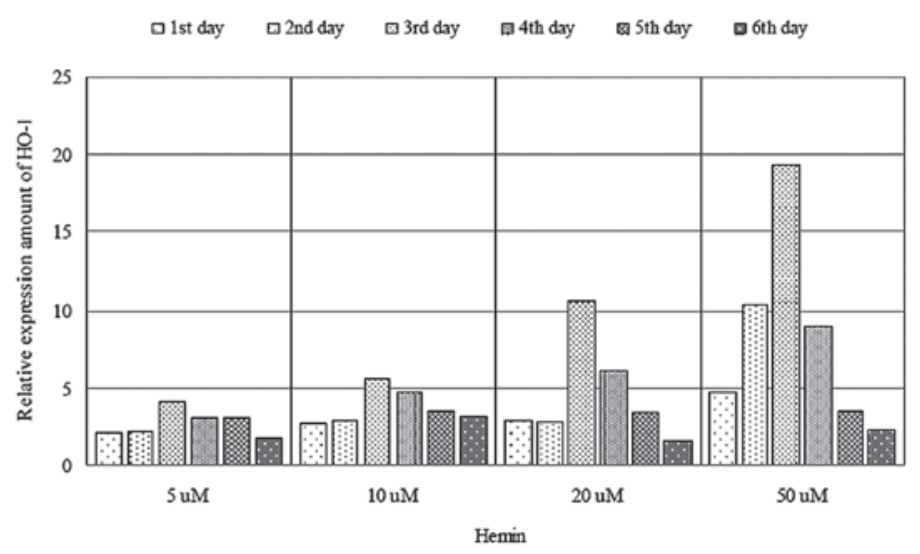

Figure 2. Relative expression levels of HO-1 induced by hemin in HepG2.2.15 hepatoma cells. The cells were treated with hemin at concentrations between 5 and $50 \mu \mathrm{M}$ for 1-6 days. $\beta$-actin was used as an internal control. $0.1 \%$ ammonia water was used as the vehicle control. HO- 1 , heme oxygenase-1.

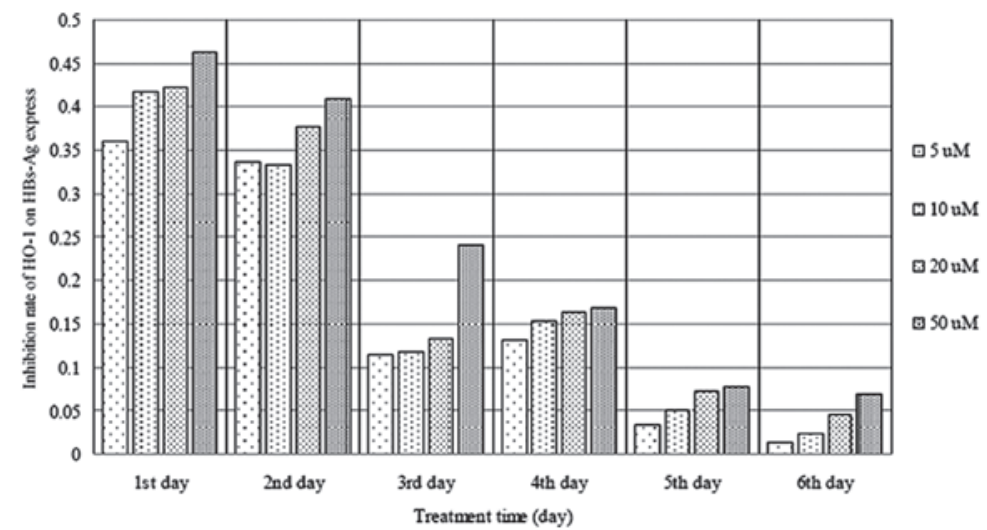

Figure 3. Effects of hemin-induced expression of HO-1 on the expression of HBsAg in HepG2.2.15 cells. The cells were treated with hemin at concentrations between 5 and $50 \mu \mathrm{M}$ for 1-6 days. $0.1 \%$ ammonia water was used as the vehicle control. HO-1, heme oxygenase-1; HBsAg, hepatitis B surface antigen.

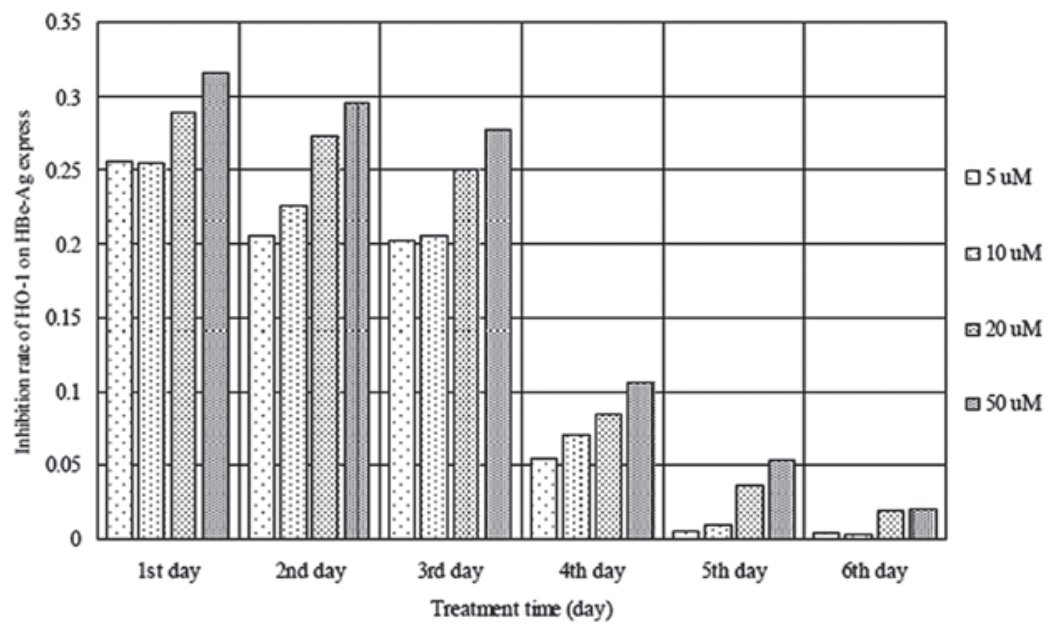

Figure 4. Effects of hemin-induced expression of HO-1 on the expression of HBeAg in HepG2.2.15 cells. The cells were treated with hemin at concentrations between 5 and $50 \mu \mathrm{M}$ for 1-6 days. $0.1 \%$ ammonia water was used as the vehicle control. HO-1, heme oxygenase-1; HBeAg, hepatitis B e antigen.

expression of HO-1 increased markedly following exposure of the cells to hemin for 1-6 days. The mRNA expression levels of HO-1 reached a peak in the hepatoma cells on the third day and subsequently reduced as the duration of exposure to hemin increased. Furthermore, the levels of HBsAg and HBeAg in the culture supernatants were significantly reduced following exposure to hemin for 1-6 days. The maximum inhibition of HBsAg and HBeAg was 37.37 and $31.73 \%$ on the first day, 
Table II. Effects of hemin-induced expression of HO-1 on HBV replication in HepG2.2.15 cells.

\begin{tabular}{|c|c|c|c|c|c|c|c|}
\hline \multirow[b]{2}{*}{ Group } & \multirow[b]{2}{*}{$\begin{array}{c}\text { Treatment } \\
\text { duration (days) }\end{array}$} & \multirow[b]{2}{*}{$\begin{array}{l}\text { Relative HO-1 } \\
\text { expression }\end{array}$} & \multicolumn{2}{|c|}{ HBsAg } & \multicolumn{2}{|c|}{ HBeAg } & \multirow[b]{2}{*}{$\log$ HBV-DNA (copy/ $/ \mu \mathrm{l})$} \\
\hline & & & Absorbance & $\begin{array}{l}\text { Inhibitory } \\
\text { rate }(\%)\end{array}$ & Absorbance & $\begin{array}{l}\text { Inhibitory } \\
\text { rate }(\%)\end{array}$ & \\
\hline \multirow[t]{6}{*}{ Vehicle } & 1 & - & $0.669 \pm 0.033$ & - & $0.562 \pm 0.038$ & - & $4.842 \pm 0.045$ \\
\hline & 2 & - & $0.791 \pm 0.030$ & - & $0.684 \pm 0.064$ & - & $4.843 \pm 0.016$ \\
\hline & 3 & - & $1.071 \pm 0.034$ & - & $1.003 \pm 0.056$ & - & $4.822 \pm 0.035$ \\
\hline & 4 & - & $1.524 \pm 0.043$ & - & $1.890 \pm 0.108$ & - & $4.722 \pm 0.022$ \\
\hline & 5 & - & $2.174 \pm 0.028$ & - & $2.020 \pm 0.063$ & - & $4.772 \pm 0.008$ \\
\hline & 6 & - & $2.367 \pm 0.110$ & - & $2.272 \pm 0.075$ & - & $4.878 \pm 0.035$ \\
\hline \multirow[t]{6}{*}{$\operatorname{Hemin}(50 \mu \mathrm{M})$} & 1 & $4.837 \pm 0.798$ & $0.413 \pm 0.047^{b}$ & 37.374 & $0.383 \pm 0.027^{b}$ & 31.729 & $4.771 \pm 0.033$ \\
\hline & 2 & $5.807 \pm 0.740$ & $0.502 \pm 0.027^{\mathrm{c}}$ & 36.498 & $0.517 \pm 0.023^{\mathrm{a}}$ & 24.415 & $4.772 \pm 0.049$ \\
\hline & 3 & $17.923 \pm 3.061$ & $0.815 \pm 0.024^{c}$ & 23.832 & $0.791 \pm 0.069^{\mathrm{a}}$ & 20.900 & $4.687 \pm 0.061^{\mathrm{a}}$ \\
\hline & 4 & $13.943 \pm 0.777$ & $1.183 \pm 0.088^{\mathrm{b}}$ & 22.193 & $1.618 \pm 0.091^{\mathrm{a}}$ & 14.392 & $4.595 \pm 0.055^{\mathrm{a}}$ \\
\hline & 5 & $5.614 \pm 1.146$ & $1.901 \pm 0.073^{\mathrm{b}}$ & 12.412 & $1.727 \pm 0.106^{\mathrm{a}}$ & 14.505 & $4.602 \pm 0.065^{\mathrm{a}}$ \\
\hline & 6 & $5.014 \pm 0.944$ & $2.112 \pm 0.084^{\mathrm{a}}$ & 10.494 & $2.093 \pm 0.048^{\mathrm{a}}$ & 7.783 & $4.639 \pm 0.094^{\mathrm{a}}$ \\
\hline
\end{tabular}

HO-1 expression levels were detected by quantitative PCR. The levels of HBsAg and HBeAg were determined by enzyme-immunoassays. The DNA expression levels of HBV were detected using a fluorescence quantitation PCR assay. The relative expression of HO-1, absorbance at $450 \mathrm{~nm}$ and $\log ^{\text {HBV-DNA }}$ values are expressed as the mean \pm standard deviation of three replicates. Inhibition $(\%)=($ mean negative control absorbance - mean experimental absorbance) / (mean negative control absorbance) x $100 \%$. $\beta$-actin was used as an internal control. $0.1 \%$ ammonia water was used as the vehicle control. ${ }^{\mathrm{a}} \mathrm{P}<0.05$, ${ }^{\mathrm{b}} \mathrm{P}<0.01$ and ${ }^{\mathrm{c}} \mathrm{P}<0.001$, compared with the vehicle control. HO- 1 , heme oxygenase 1 ; HBsAg, hepatitis B surface antigen; HBeAg, hepatitis B e antigen; PCR, polymerase chain reaction.

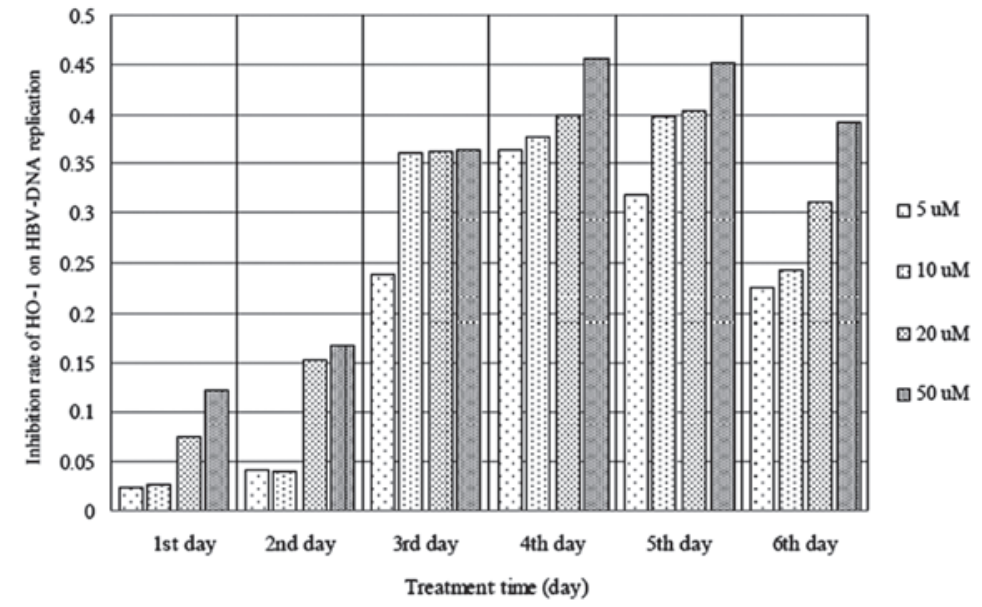

Figure 5. Effects of hemin-induced expression of HO-1 on HBV DNA replication in HepG2.2.15 cells. The cells were treated with hemin at concentrations between 5 and $50 \mu \mathrm{M}$ for 1-6 days. $0.1 \%$ ammonia water was used as the vehicle control. HO-1, heme oxygenase-1; HBV, hepatitis B virus.

respectively; whereas inhibition of the expression levels of HBsAg and HBeAg decreased with increasing duration of exposure to hemin. By contrast, as the duration of hemin exposure increased, the inhibition of HBV DNA replication increased. Furthermore, the expression levels of HBV DNA were markedly reduced following exposure to hemin for 3-6 days, and reached their lowest levels on the fourth day.

\section{Discussion}

The HO system includes the heme catabolic pathway, which is comprised of $\mathrm{HO}$ and biliverdin reductase and the products of heme degradation, carbon monoxide, iron and biliverdin/bilirubin $(11,12)$. As a protective enzyme, the relevance of $\mathrm{HO}-1$ in humans and animals has been demonstrated in the case of HO-1 deficiency, which results in severe tissue damage due to oxidative stress and in multiple consecutive disorders (13-15). HO-1 and the reaction products of heme degradation have been associated with cytoprotection, due to their anti-inflammatory, antioxidative, and anti-apoptotic effects $(8,16)$. Furthermore, the induction of HO-1 or application of its products has been observed to lead to a broad range of hepatoprotective effects in animal models of acute and chronic hepatitis (7). The effects of HO-1 include preventing and attenuating liver injury (17-22), 
protecting from liver fibrosis (23), interrupting the progression of nutritional steatohepatitis $(24,25)$, preserving hepatic architecture (26), improving liver function $(26,27)$ and providing protection against severe ischemia/reperfusion injury (27-30). Therefore, HO-1 offers a promising novel target in drug development, and the implementation of clinical approaches to moderate and alleviate the numerous chronic disorders affected by perturbations in the HO system (31).

It has been demonstrated that the induction or overexpression of HO-1 interfered with the viral replication of hepatitis $\mathrm{B}$ and $\mathrm{C}(8,32-35)$. HO-1 induction results in a marked antiviral effect in the adenoviral transfer of the HBV 1.3 genome into wild type mice and HBV transgenic animal models of acute and chronic HBV infection, respectively (8). Investigation into the effects of HO-1 on HBV replication in hepatoma cells stably transfected with HBV have revealed that induction of HO-1 directly suppressed HBV replication in hepatocytes at the posttranscriptional level by reducing the stability of the HBV core protein, inhibiting the refill of nuclear HBV cccDNA (8). Furthermore, it has been reported that microRNA-122, which is abundantly expressed in the human liver, interferes with the expression of HO-1, thereby promoting HBV replication $(32,36)$. Conversely, $\mathrm{HO}-1$ is overexpressed in various types of tumor, including hepatocellular carcinoma, and inhibiting the expression or activity of HO-1 promotes the apoptosis of cancer cells (37-39). Although its anti-apoptotic property risks the promotion of tumor growth (7), the induction of HO-1 may become a useful adjuvant for the clinical therapy of viral hepatitis.

HepG2.2.15 cells were initially derived from the HepG2 human hepatoblastoma cells, which were transfected with a plasmid containing HBV DNA. These transfected cells can stably secrete viral particles into culture medium (40). This in vitro system can be used to investigate the life cycle of $\mathrm{HBV}$, and the reaction of immunocompetent cells to those containing HBV DNA (9). The present study investigated the dynamic correlation between the expression of HO-1 and HBV replication in HepG2.2.15 cells following exposure to various concentrations of hemin for 1-6 days. The initial comparative investigation of HO-1 expression levels following exposure to different concentrations of hemin demonstrated that hemin (5-50 $\mu \mathrm{M})$ significantly induced the expression of HO-1. The mRNA expression levels of HO-1 increased in a dose-dependent manner and reached a peak following exposure to hemin for 3 days. However, the expression levels of HO-1 decreased with further extension of the duration of exposure to hemin, possibly due to the functions of HO-1 as a stress-responsive enzyme (41). The present study also investigated the levels of HBsAg and HBeAg following exposure to various concentrations of hemin. The results demonstrated that the expression levels of HBsAg and HBeAg were markedly inhibited following exposure to hemin for 1-6 days. Measurement of expression of HBV DNA following exposure to various concentrations of hemin demonstrated that HBV DNA replication was significantly inhibited in a time-dependent manner. These data suggested that the secretion of $\mathrm{HBs} \mathrm{Ag} / \mathrm{HBeAg}$ and HBV DNA replication were inhibited with increasing expression levels of HO-1. Furthermore, as the duration of hemin exposure increased the inhibition of HBV DNA replication was more marked, implying that the reduction of HBV replication may contribute to the induction of the HO-1 gene.
To further understand the correlation between the induction of HO-1 and HBV replication, the gene expression of HO-1 was induced in HepG2.2.15 cells by hemin at the optimal concentration of $50 \mu \mathrm{M}$ for 1-6 days. The significant elevation in the mRNA expression of HO-1 peaked on the fourth day, and subsequently reduced with further extension of the duration of exposure to hemin. Furthermore, the HBsAg and $\mathrm{HBeAg}$ levels in the cell culture supernatants were significantly reduced following exposure to hemin for 1-6 days. This marked reduction in the expression of $\mathrm{HBsAg}$ and $\mathrm{HBeAg}$ peaked on the first day, and the inhibition was weakened as the duration of exposure to hemin increased. Conversely, the inhibition of HBV DNA replication increased with increasing duration of exposure. Furthermore, DNA expression levels of HBV were significantly decreased following exposure to hemin for 3-6 days. The effects of hemin-induced HO-1 on HBsAg and $\mathrm{HBeAg}$ were different from those on HBV DNA. This may be associated with a non-significant correlation between either HBsAg or HBeAg levels, and HBV DNA levels $(40,42)$. The present study demonstrated that the marked upregulation in the expression of HO-1 following treatment with hemin attenuated HBV replication in the HepG2.2.15 cells, indicating that pharmacologically inducing overexpression of $\mathrm{HO}-1$ may provide protection against HBV infection. Furthermore, the downregulation of HBV replication in the cells may be associated with the reaction products of heme degradation and the inhibition of HBV reverse transcriptase (RT)- $\varepsilon$ RNA interaction by hemin $(7,43)$. HBV-RT has numerous roles in the viral life cycle and is an essential target for the development of anti-HBV chemotherapy; hemin was found to block RT interactions with viral RNA packaging signal/origin of replication $\varepsilon$, therefore suppressing the protein-priming reaction (43). Although the induction or overexpression of HO-1 may assist as an adjuvant for clinical therapy, no specific HO-1 inducers are currently available, despite attempts, including the use of miR-196 or antagomiR-122, direct silencing of the HO-1 transcriptional repressor Bach-1 by siRNA and the use of HO-1 coupled to a protein transduction domain (7). HO-1 and its products possess a significant curative potential that may assist in the treatment of patients with hepatitis.

In conclusion, the present study clarified the dynamic correlation between the hemin-induced expression of $\mathrm{HO}-1$ and HBV replication in HepG2.2.15 cells. The upregulation of HO-1 interfered with HBV replication in a dose- and time-dependent manner. The secretion of HBsAg and HBeAg, and HBV DNA replication were inhibited with induction of the expression of HO-1, suggesting that a reduction in the HBV viral load may be contributed to by overexpression of HO-1.

\section{Acknowledgements}

The present study was supported by the Zhejiang Provincial Natural Science Foundation of China (grant no. Y14H310024), the Key Project of Chinese Ministry of Education (grant no. 212073) and the Public Welfare Technology Applied Research Project of Zhejiang Province-Experimental Animal Science and Technology Project (grant no. 2013C37020). The authors are grateful to Professor Hangping Yao (State Key Laboratory for Diagnosis and Treatment of Infectious Diseases at Zhejiang University) for kindly providing the HepG2.2.15 cells. 


\section{References}

1. Hollinger FB and Liang TJ: Hepatitis B virus. In: Fields Virology. Knipe DM and Howley PM (eds.). Lippincott Williams \& Wilkins, Philadelphia, pp2971-3036, 2001.

2. Wu YH, Hao BJ, Cao HC, Xu W, Li YJ and Li LJ: Anti-hepatitis $B$ virus effect and possible mechanism of action of 3,4-o-dicaffeoylquinic acid in vitro and in vivo. Evid Based Complement Alternat Med 2012: 356806, 2012.

3. Delaney WE IV, Locarnini S and Shaw T: Resistance of hepatitis B virus to antiviral drugs: current aspects and directions for future investigation. Antivir Chem Chemother 12: 1-35, 2001.

4. Maines MD, Trakshel GM and Kutty RK: Characterization of two constitutive forms of rat liver microsomal heme oxygenase. Only one molecular species of the enzyme is inducible. J Biol Chem 261: 411-419, 1986.

5. Maines MD: Heme oxygenase: function, multiplicity, regulatory mechanisms, and clinical applications. FASEB J 2: 2557-2568, 1988

6. Otterbein LE and Choi AM: Heme oxygenase: colors of defense against cellular stress. Am J Physiol Lung Cell Mol Physiol 279: L1029-L1037, 2000.

7. Sass G, Barikbin R and Tiegs G: The multiple functions of heme oxygenase-1 in the liver. Z Gastroenterol 50: 34-40, 2012.

8. Protzer U, Seyfried S, Quasdorff M, et al: Antiviral activity and hepatoprotection by heme oxygenase-1 in hepatitis B virus infection. Gastroenterology 133: 1156-1165, 2007

9. Sells MA, Chen ML and Acs G: Production of hepatitis B virus particles in Hep G2 cells transfected with cloned hepatitis B virus DNA. Proc Natl Acad Sci USA 84: 1005-1009, 1987.

10. Livak KJ and Schmittgen TD: Analysis of relative gene expression data using real-time quantitative PCR and the 2(-delta delta C(T)) method. Methods 25: 402-408, 2001.

11. Tenhunen R, Marver HS and Schmid R: The enzymatic conversion of heme to bilirubin by microsomal heme oxygenase. Proc Natl Acad Sci USA 61: 748-755, 1968.

12. Tenhunen R, Marver H, Pimstone NR, Trager WF, Cooper DY and Schmid R: Enzymatic degradation of heme. Oxygenative cleavage requiring cytochrome P-450. Biochemistry 11: 1716-1720, 1972.

13. Yachie A, Niida Y, Wada T, Igarashi N, Kaneda H, Toma T, Ohta K Kasahara Y and Koizumi S: Oxidative stress causes enhanced endothelial cell injury in human heme oxygenase-1 deficiency. J Clin Invest 103: 129-135, 1999.

14. Kawashima A, Oda Y, Yachie A, Koizumi S and Nakanishi I: Heme oxygenase-1 deficiency: the first autopsy case. Hum Pathol 33: 125-130, 2002.

15. Schulz S, Wong RJ, Jang KY, Kalish F, Chisholm KM, Zhao H, Vreman HJ, Sylvester KG and Stevenson DK: Heme oxygenase-1 deficiency promotes the development of necrotizing enterocolitis-like intestinal injury in a newborn mouse model. Am J Physiol Gastrointest Liver Physiol 304: G991-G1001, 2013.

16. Immenschuh S, Baumgart-Vogt E and Mueller S: Heme oxygenase-1 and iron in liver inflammation: a complex alliance. Curr Drug Targets 11: 1541-1550, 2010.

17. Zuckerbraun BS, Billiar TR, Otterbein SL, Kim PK, Liu F, Choi AM, Bach FH and Otterbein LE: Carbon monoxide protects against liver failure through nitric oxide-induced heme oxygenase 1. J Exp Med 198: 1707-1716, 2003.

18. Sass G, Soares MC, Yamashita K, Seyfried S, Zimmermann WH, Eschenhagen T, Kaczmarek E, Ritter T, Volk HD and Tiegs G: Heme oxygenase-1 and its reaction product, carbon monoxide, prevent inflammation-related apoptotic liver damage in mice. Hepatology 38: 909-918, 2003

19. Sass G, Seyfried S, Parreira Soares M, Yamashita K, Kaczmarek E, Neuhuber WL and Tiegs G: Cooperative effect of biliverdin and carbon monoxide on survival of mice in immune-mediated liver injury. Hepatology 40: 1128-1135, 2004.

20. Chang KY, Tsai PS, Huang TY, Wang TY, Yang S and Huang CJ: $\mathrm{HO}-1$ mediates the effects of $\mathrm{HBO}$ pretreatment against sepsis. J Surg Res 136: 143-153, 2006.

21. Wen T, Guan L, Zhang YL and Zhao JY: Dynamic changes of heme oxygenase- 1 and carbon monoxide production in acute liver injury induced by carbon tetrachloride in rats. Toxicology 228: 51-57, 2006

22. Wen T, Wu ZM, Liu Y, Tan YF, Ren F and Wu H: Upregulation of heme oxygenase-1 with hemin prevents D-galactosamine and lipopolysaccharide-induced acute hepatic injury in rats. Toxicology 237: 184-193, 2007.

23. Barikbin R, Neureiter D, Wirth J, Erhardt A, Schwinge D, Kluwe J, Schramm C, Tiegs G and Sass G: Induction of heme oxygenase 1 prevents progression of liver fibrosis in Mdr2 knockout mice. Hepatology 55: 553-562, 2012.
24. Nan Y, Wang R, Zhao S, Han F, Wu WJ, Kong L, Fu N, Kong L and Yu J: Heme oxygenase-1 prevents non-alcoholic steatohepatitis through suppressing hepatocyte apoptosis in mice. Lipids Health Dis 9: 124, 2010.

25. Yu J, Chu ES, Wang R, Wang S, Wu CW, Wong VW, Chan HL, Farrell GC and Sung JJ: Heme oxygenase-1 protects against steatohepatitis in both cultured hepatocytes and mice. Gastroenterology 138: 694-704, 2010.

26. McCarter SD, Badhwar A, Scott JR, Akyea TG, Bihari A, Dungey AA, Harris KA and Potter RF: Remote liver injury is attenuated by adenovirus-mediated gene transfer of heme oxygenase- 1 during the systemic inflammatory response syndrome. Microcirculation 11: 587-595, 2004.

27. Amersi F, Buelow R, Kato H, Ke B, Coito AJ, Shen XD, Zhao D, Zaky J, Melinek J, Lassman CR, et al: Upregulation of heme oxygenase-1 protects genetically fat Zucker rat livers from ischemia/reperfusion injury. J Clin Invest 104: 1631-1639, 1999.

28. Amersi F, Shen XD, Anselmo D, Melinek J, Iyer S, Southard DJ, Katori M, Volk HD, Busuttil RW, et al: Ex vivo exposure to carbon monoxide prevents hepatic ischemia/reperfusion injury through p38 MAP kinase pathway. Hepatology 35: 815-823, 2002.

29. Kato H, Amersi F, Buelow R, Melinek J, Coito AJ, Ke B, Busuttil RW and Kupiec-Weglinski JW: Heme oxygenase-1 overexpression protects rat livers from ischemia/reperfusion injury with extended cold preservation. Am J Transplant 1: 121-128, 2001.

30. Kim SJ,Park JG and Lee SM: Protective effect of heme oxygenase-1 induction against hepatic injury in alcoholic steatotic liver exposed to cold ischemia/reperfusion. Life Sci 90: 169-176, 2012.

31. Abraham NG and Kappas A: Pharmacological and clinical aspects of heme oxygenase. Pharmacol Rev 60: 79-127, 2008.

32. Qiu L, Fan H, Jin W, Zhao B, Wang Y, Ju Y, Chen L, Chen Y, Duan $Z$ and Meng S: miR-122-induced down-regulation of HO-1 negatively affects miR-122-mediated suppression of HBV. Biochem Biophys Res Commun 398: 771-777, 2010.

33. Zhu Z, Wilson AT, Mathahs MM, Wen F, Brown KE, Luxon BA and Schmidt WN: Heme oxygenase-1 suppresses hepatitis $C$ virus replication and increases resistance of hepatocytes to oxidant injury. Hepatology 48: 1430-1439, 2008.

34. Lehmann E, El-Tantawy WH, Ocker M, Bartenschlager R, Lohmann V, Hashemolhosseini S, Tiegs G and Sass G: The heme oxygenase 1 product biliverdin interferes with HCV replication by increasing antiviral interferon response. Hepatology 51: 398-404, 2010 .

35. Shan Y, Zheng J, Lambrecht RW and Bonkovsky HL: Reciprocal effects of micro-RNA-122 on expression of heme oxygenase- 1 and hepatitis C virus genes in human hepatocytes. Gastroenterology 133: 1166-1174, 2007.

36. Chang J, Nicolas E, Marks D, Sander C, Lerro A, Buendia MA, Xu C, Mason WS, Moloshok T, Bort R, Zaret KS and Taylor JM: miR-122, a mammalian liver-specific microRNA, is processed from hor mRNA and may downregulate the high affinity cationic amino acid transporter CAT-1. RNA Biol 1: 106-113, 2004.

37. Lee J, Lee SK, Lee BU, Lee HJ, Cho NP, Yoon JH, Choi HR, Lee SK and Kim EC: Upregulation of heme oxygenase-1 in oral epithelial dysplasias. Int J Oral Maxillofac Surg 37: 287-292, 2008.

38. Nuhn P, Künzli BM, Hennig R, Mitkus T, Ramanauskas T, Nobiling R, Meuer SC, Friess $\mathrm{H}$ and Berberat PO: Heme oxygenase- 1 and its metabolites affect pancreatic tumor growth in vivo. Mol Cancer 8: 37, 2009.

39. Sass G, Leukel P, Schmitz V, Raskopf E, Ocker M, Neureiter D, Meissnitzer M, Tasika E, Tannapfel A and Tiegs G: Inhibition of heme oxygenase 1 expression by small interfering RNA decreases orthotopic tumor growth in livers of mice. Int J Cancer 123: 1269-1277, 2008.

40. Sureau C, Romet-Lemonne JL, Mullins JI and Essex M: Production of hepatitis B virus by a differentiated human hepatoma cell line after transfection with cloned circular HBV DNA. Cell 47: 37-47, 1986.

41. Elbirt KK and Bonkovsky HL: Heme oxygenase: recent advances in understanding its regulation and role. Proc Assoc Am Physicians 111: 438-447, 1999.

42. Wiegand J, Wedemeyer H, Finger A, Heidrich B, Rosenau J, Michel G, Bock CT, Manns MP and Tillmann HL: A decline in hepatitis B virus surface antigen (hbsag) predicts clearance, but does not correlate with quantitative hbeag or HBV DNA levels. Antivir Ther 13: 547-554, 2008.

43. Lin $\mathrm{L}$ and $\mathrm{Hu} \mathrm{J}$ : Inhibition of hepadnavirus reverse transcriptase-epsilon RNA interaction by porphyrin compounds. J Virol 82: 2305-2312, 2008. 